\title{
4-Hexylresorcinol Administration Increases Dental Hard Tissue Formation and Incisor Eruption Rate in Rats
}

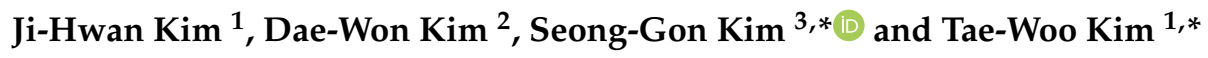 \\ 1 Department of Orthodontics, School of Dentistry, Seoul National University, Seoul 3080, Korea; \\ hwankim29@gmail.com \\ 2 Department of Oral Biochemistry, College of Dentistry, Gangneung-Wonju National University, \\ Gangneung 28644, Korea; kimdw@gwnu.ac.kr \\ 3 Department of Oral and Maxillofacial Surgery, College of Dentistry, Gangneung-Wonju National University, \\ Gangneung 28644, Korea \\ * Correspondence: kimsg@gwnu.ac.kr (S.-G.K.); taewoo@snu.ac.kr (T.-W.K.); Tel.:+82-33-640-2468 (S.-G.K.); \\ +82-2-2072-3317 (T.-W.K.)
}

Received: 17 July 2020; Accepted: 5 August 2020; Published: 10 August 2020

\section{Featured Application: The administration of 4-hexylresorcinol enhances mineralization during} tooth formation.

\begin{abstract}
Dental hard tissue formation and bone turnover are required for tooth eruption. 4-Hexylresorcinol (4HR) accelerates tooth movement by increasing bone turnover in orthodontic treatment. This study aimed to evaluate the following: (1) the effect of $4 \mathrm{HR}$ application on the expression of proteins associated with tooth formation, and (2) the effect of $4 \mathrm{HR}$ application on mandibular incisor eruption rate in a rat model. Primary cultured pulp cells received either $4 \mathrm{HR}$ (1 to $100 \mu \mathrm{M}$ ) or solvent only; western blotting was performed for transforming growth factor-beta 1 (TGF- $\beta 1$ ), bone morphogenic protein-2/4 (BMP-2/4), runt-related transcription factor 2 (Runx2), osterix (OSX), dentin sialophosphoprotein (DSPP), and parathyroid hormone-related protein receptor (PTHrP-R). In in vivo study, rats (15 males and 15 females) received either solvent or $0.128 \mathrm{mg} / \mathrm{kg}$ or $12.8 \mathrm{mg} / \mathrm{kg}$ of $4 \mathrm{HR}$ via subcutaneous injection; mandibular incisor eruption rate was subsequently recorded. Immunohistochemical staining and western blotting for TGF- $\beta 1$, BMP-2/4, Runx2, OSX, DSPP, and PTHrP-R were performed in the mandibular tissue samples. 4HR administration was found to increase TGF- $\beta 1$, BMP-2/4, Runx2, OSX, DSPP, and PTHrP-R expression in both cell culture and tissue samples. Immunohistochemical staining of some markers showed site-specific expression, thereby indicating programmed differentiation of odontoblasts and ameloblasts. The eruption rate was significantly higher in the $12.8 \mathrm{mg} / \mathrm{kg} 4 \mathrm{HR}$-administered group than in the untreated control $(p=0.001$ and 0.010 for males and females, respectively). Collectively, $4 \mathrm{HR}$ administration increased the expression of markers related to dental hard tissue formation and accelerated the eruption rate of incisors in rats.
\end{abstract}

Keywords: 4-hexylresorcinol; incisor eruption; dental hard tissue formation

\section{Introduction}

Tooth eruption is a biological process induced by the interaction between bone resorption, bone formation, and dental hard tissue formation [1]. The latter helps the tooth to move in the alveolar bone due to the force of root formation in the pre-emergent and post-emergent eruptive stages [2]. 
The incisors of rodents erupt continuously due to the constant formation of dental hard tissue to compensate for dental attrition [3].

Many molecules related to bone resorption, bone formation, and dental hard tissue formation are known to control the process of tooth eruption [4]. Transforming growth factor-beta 1 (TGF- $\beta 1$ ) plays an important role in cell proliferation and differentiation related to bone metabolism and tooth formation [5]. While bone morphogenic protein-2 (BMP-2) is a key molecule for osteogenesis, runt-related transcription factor 2 (Runx2) [6-8] and osterix (OSX) [8-10] are involved in osteoblast, odontoblast, and ameloblast differentiation, eventually leading to bone and teeth formation. Dentin sialophosphoprotein (DSPP) is important for dentin formation, which in turn, is critical for root formation [8].

When proper molecular regulations are inhibited, normal eruption of teeth can also be inhibited or delayed. Some endocrine disorders, including hypothyroidism, hypopituitarism, and hypoparathyroidism, are associated with delayed tooth eruption due to abnormal calcium metabolism [11,12]. Cleidocranial dysplasia is a genetic disease that shows many impacted teeth, caused by mutations in the RUNX2 gene [13]. In the absence of parathyroid hormone-related protein (PTHrP) expression, tooth eruption and root formation do not occur normally [14]. Primary failure of eruption (PFE) [15], a rare condition that inhibits the eruption of particular teeth nonsyndromically, was found to be related to a mutation of the PTH1R (Parathyroid Hormone 1 Receptor) gene [16,17]. Tooth eruption can also be delayed or inhibited in conditions in which proper dental hard tissue formation does not occur, such as amelogenesis imperfecta or dentin dysplasia [12].

In rat incisors, the odontogenic region with the enamel organ, dental papilla, and dental follicle is maintained even after the eruption of a tooth, resulting in the continuous formation of enamel and dentin. Therefore, rat incisors are good models to study the mechanism of dental hard tissue formation, which plays an important role in the regulation of the eruption process [3]. A few studies have previously reported the effects of several methods, in which molecular reactions caused a change in the eruption rate of rat incisors. Medications known to inhibit bone resorption, such as bisphosphonate [18] and alendronate [19], resulted in delayed tooth eruption; high-dose radiotherapy also slowed the rate of eruption with histologic alterations in the odontogenic region [20]. However, studies reporting an increased eruption rate due to the effect of chemicals are rare.

4-Hexylresorcinol (4HR) is a multifunctional organic molecule that has been studied actively in tissue engineering [21]. In bone biology, $4 \mathrm{HR}$ suppresses the nuclear factor kappa B (NFkB) signaling pathway, consequently increasing new bone formation [22]; a recent study has shown the administration of $4 \mathrm{HR}$ to accelerate orthodontic tooth movement by increasing bone turnover rate in ovariectomized rats [23]. Tooth eruption may have features similar to those in orthodontic tooth movement, in which bone turnover is required. However, there are differences as well, since bone turnover during the tooth eruption process is orchestrated genetically, whereas that in orthodontics is regulated by mechanical force [24]. Another critical difference is that both dental hard tissue formation and bone turnover are required for tooth eruption.

This study aimed to evaluate the effects of $4 \mathrm{HR}$ administration on dental hard tissue formation along with the eruption rate in rat incisors.

\section{Materials and Methods}

\subsection{Cell Culture and $4 H R$ Treatment}

Pulp tissues were collected from rat mandibular incisors. Extracted teeth were collected in serum-free media. After being washed in phosphate-buffered saline (PBS) (CAT\# 17-602E, Lonza, Walkersville, MD, USA), fresh pulp tissue was chopped and placed on a culture dish. Chopped tissue was treated with $3 \mathrm{mg} / \mathrm{mL}$ of type I collagenase (CAT\# 17100017, Gibco ${ }^{\mathrm{TM}}$, Carlsbad, CA, USA) at $37^{\circ} \mathrm{C}$ for $2 \mathrm{~h}$. Cells were isolated using a 70- $\mu \mathrm{m}$ strainer (CAT\# 93070, SPL Life Sciences, Pocheon-si, Korea). The complete medium used was minimum essential medium $\alpha$ (CAT\# SH30265, Hyclone Laboratories, 
Logan, UT, USA) supplemented with 10\% fetal bovine serum (FBS) (CAT\# 12483020, Gibco ${ }^{\mathrm{TM}}$ ), $50 \mathrm{U} / \mathrm{mL}$ of penicillin $\mathrm{G}, 50 \mu \mathrm{g} / \mathrm{mL}$ of streptomycin sulfate, $2 \mathrm{~g} / \mathrm{L}$ of sodium carbonate, and $0.11 \mathrm{~g} / \mathrm{L}$ of sodium pyruvate. The collected sample was mixed with $10 \mathrm{~mL}$ of the complete medium and centrifuged at 15,000 rpm for $10 \mathrm{~min}$. Cells were suspended in the complete medium and placed on a 60-mm Petri dish. 4HR was procured from Sigma-Aldrich (St. Louis, MO, USA). Dimethyl sulfoxide (DMSO) was used as solvent for $4 \mathrm{HR}$ and diluted in the culture medium.

\subsection{Western Blotting for TGF- $\beta 1, B M P-2 / 4$, Runx2, OSX, DSPP, and PTHrP-R}

In this study, primary antibodies for TGF- $\beta 1$, BMP-2/4, Runx2, OSX, DSPP, and PTHrP-receptor (PTHrP-R) were used, and all of them were purchased from Santa Cruz Biotech (Santa Cruz, CA, USA). Primary cultured pulp cells were treated with 1,10 , or $100 \mu \mathrm{M} 4 \mathrm{HR}$. The untreated control received only solvent. Cells were collected at 2, 8, or $24 \mathrm{~h}$ after $4 \mathrm{HR}$ treatment. For collecting cells, culture dishes were washed with PBS and treated with trypsin-ethylene diamine tetra-acetic acid (trypsin-EDTA) for $1 \mathrm{~min}$. Thereafter, cells were washed with PBS again. Collected cells were lysed in chilled radio-immunoprecipitation assay (RIPA) buffer and sonicated for $10 \mathrm{~s}$. After centrifugation $\left(12,000 \times g\right.$ for $10 \mathrm{~min}$ at $\left.4^{\circ} \mathrm{C}\right)$, the concentration of protein was measured by the Bradford method. Equal amounts of proteins were loaded on $15 \%$ sodium dodecyl sulfate-polyacrylamide gel and separated by electrophoresis. Separated proteins were transferred to a nitrocellulose membrane. The nitrocellulose membrane was blocked with 5\% non-fat dry milk in TBS-T buffer (Tris-buffered saline, $25 \mathrm{mM}$ Tris-HCl, $150 \mathrm{mM} \mathrm{NaCl}, 0.1 \%$ Tween 20, $\mathrm{pH}$ 7.5) for $1 \mathrm{~h}$. After several washing steps, the membrane was incubated with primary antibodies (dilution ratio $=1: 500$ ) and horseradish peroxidase-conjugated secondary antibodies for $1 \mathrm{~h}$. The protein bands were detected using an enhanced chemiluminescent kit. Blot images were taken and quantified using a ChemiDoc XRS system (Bio-Rad Laboratories, Hercules, CA, USA).

\subsection{Animals and Experimental Design}

A total of 30 rats (4-week-old Crl:CD specific pathogen-free/viral antibody-free) were purchased from Orientbio Inc. (Sungnam, Korea). All procedures were performed in accordance with the guidelines for laboratory animal care and approved by the Gangneung-Wonju National University (GWNU-2020-10). All rats were caged individually and fed as described previously [22,25]. One week was allowed for acclimation before commencing the experiments. The right lower incisor of each rat was cut at the level of interdental papilla using a nail cutter.

The rats were divided into 3 groups, each with 10 rats ( 5 males and 5 females). The control group was administered only solvent; either high- or low-dosage $4 \mathrm{HR}$ was injected into the experimental groups. The drug was injected on the second day after cutting the incisor; dosage was $0.128 \mathrm{mg} / \mathrm{kg}$ (Group A) or $12.8 \mathrm{mg} / \mathrm{kg}$ (Group B) of $4 \mathrm{HR}$. Each dosage was prepared just before injection and injected subcutaneously into the submental space. The incisor was cut regularly, as per a predetermined schedule, at an approximate interval of 2.5 days for 18 days. The eruption rate was determined by measuring the cut fragment. The total eruption was considered as the sum of each measurement. After 18 days of injection, all animals were sacrificed. The mandible was extirpated for further analysis.

\subsection{Immunohistochemical Determination and Western Blot Analysis of Mandibular Samples}

To assess the expression levels of TGF- $\beta 1$, BMP-2/4, Runx2, OSX, DSPP, and PTHrP-R in the mandibular samples, we performed immunohistochemical staining using anti-TGF- $\beta 1$, anti-BMP-2/4, anti-Runx2, anti-OSX, anti-DSPP, and anti-PTHrP-R antibodies (Santa Cruz Biotech), as per the procedure described in our previous publications [25]. Briefly, 10- $\mu \mathrm{m}$ thick paraffin sections were prepared on coated slides. After a deparaffinization and subsequent hydration procedure, a proteolytic enzyme ( $1 \mathrm{mg}$ porcine trypsin, Sigma-Aldrich) was applied for antigen retrieval. Endogenous peroxidase activity was inhibited by $\mathrm{H}_{2} \mathrm{O}_{2}$ application. After washing in PBS, the protein blocking procedure was performed for $1 \mathrm{~h}$. The sections were treated with primary antibodies (dilution ratio 
1:50) and incubated at $4{ }^{\circ} \mathrm{C}$ overnight. After washing in PBS, EnVision ${ }^{\mathrm{TM}}$ (Dako North America Inc., Carpinteria, CA, USA) was applied on the slide in the humid chamber for $30 \mathrm{~min}$. After removing the unreacted secondary antibody, the slide was stained with a chromogen (Dako REAL ${ }^{\mathrm{TM}} \mathrm{DAB}+$ Chromogen and Dako REAL ${ }^{\mathrm{TM}}$ Substrate Buffer; Dako North America Inc, Carpinteria, CA, USA).

Fresh tissues from the mandible were placed into cryo-tubes and stored at $-80{ }^{\circ} \mathrm{C}(\mathrm{n}=5$ for each group). For protein extraction, tissues were crushed and homogenized, and treated with tissue protein extraction reagent buffer containing a protease inhibitor cocktail. After determining the protein concentration, western blot analysis was conducted. Subsequent procedure was in accordance with those described previously [25].

\subsection{Statistical Analysis}

Comparison across the three groups was performed based on analysis of variance (ANOVA). For comparing between groups, after ANOVA, a post-hoc test was conducted using the Bonferroni method. The level of significance was set as $<0.05$.

\section{Results}

\subsection{Application of 4HR Increased TGF- $\beta 1$, OSX, DSPP, Runx2, BMP-2/4, and PTHrP-R Expression in Primary Cultured Pulp Cells}

Administration of $4 \mathrm{HR}$ increased the expression levels of TGF- $\beta 1$, OSX, DSPP, PTHrP-R, BMP-2/4, and Runx2, in a dose- and time-dependent manner (Figure 1). Full length blot images and relative expression level are available in supplementary data (Figures S1 and S2).

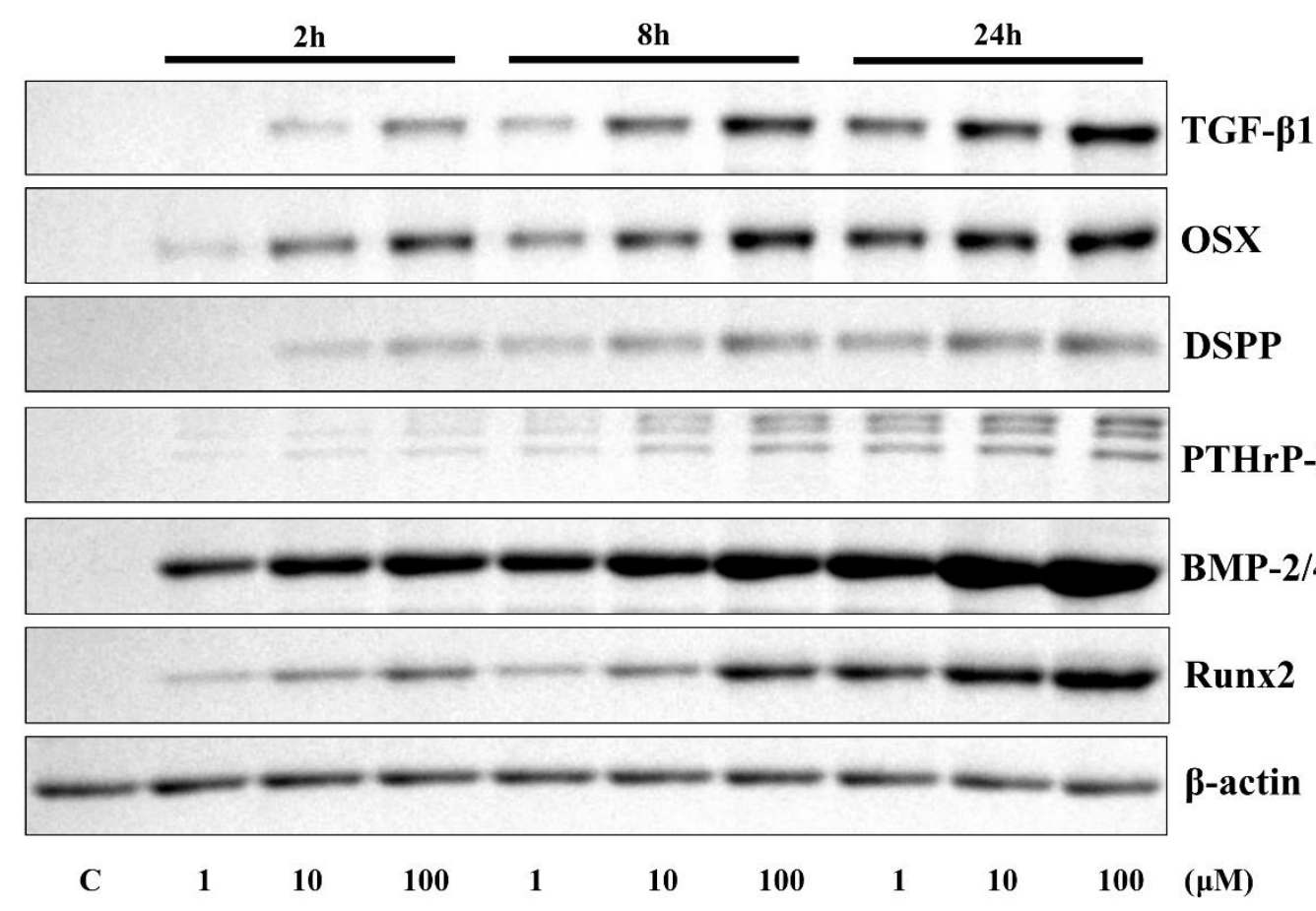

Figure 1. Results of western blotting assay for cell culture. Application of 4-hexylresorcinol (4HR) increased the expression levels of TGF- $\beta 1$ (transforming growth factor-beta 1), OSX (osterix), DSPP (dentin sialophosphoprotein), PTHrP-R (parathyroid hormone-related protein receptor), BMP-2/4 (bone morphogenic protein-2/4), and Runx2 (runt-related transcription factor 2) in a time- and dose-dependent manner. 


\subsection{HR Increased the Rate of Incisor Eruption in the Rat Model}

The administration of $4 \mathrm{HR}$ increased the rate of incisor eruption in both sexes of rats (Figure 2). When the total amount of eruption was compared between males and females, there was no significant difference between the sexes in the same group $(p>0.05)$. The total amount of eruption in males at 15 days after $4 \mathrm{HR}$ administration was $21.75 \pm 0.83,23.49 \pm 0.94$, and $24.76 \pm 0.91 \mathrm{~mm}$ in control, Group A, and Group B, respectively. The difference across the groups was statistically significant $(p=0.001)$. In the post-hoc test, the difference between control and experimental groups was statistically significant $(p=0.028$ and 0.001 for Groups A and B, respectively). However, there was no statistically significant difference between Groups A and B ( $p>0.05)$.

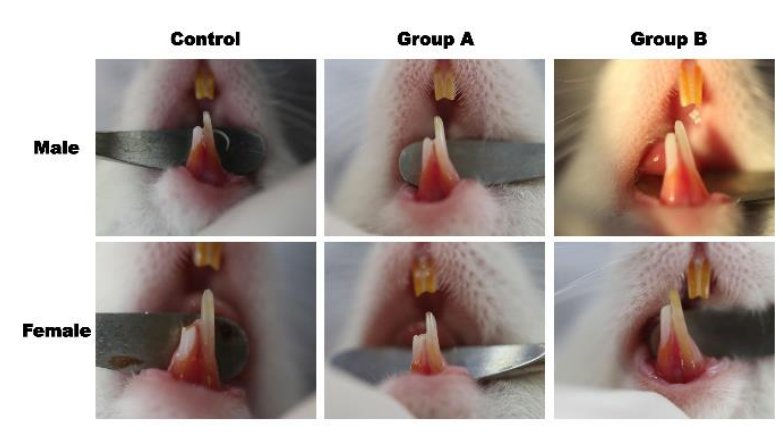

(a)

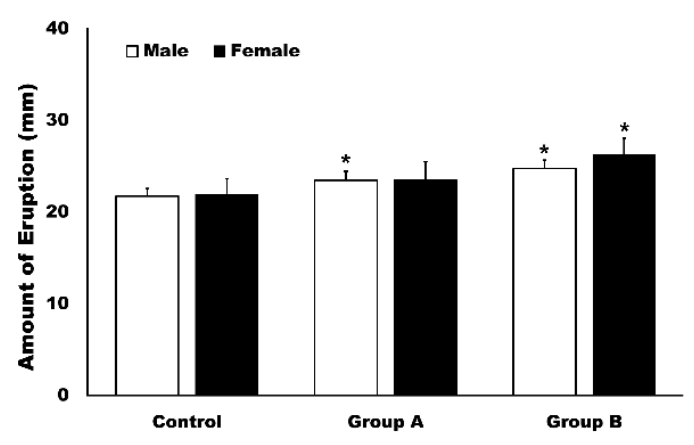

(b)

Figure 2. Results of tooth eruption study. (a) Representative findings after $4 \mathrm{HR}$ administration. Administration of $4 \mathrm{HR}$ increased the rate of incisor eruption. (b) Cumulative amount of incisor eruption. Compared to the control, the high-dosage group (Group B) showed statistically significant difference $\left({ }^{*} p<0.05\right)$. In the case of the low-dosage group (Group A), only the male group showed statistically significant difference compared to the control $(* p<0.05)$.

The total amount of eruption in females after 15 days of $4 \mathrm{HR}$ administration was $22.00 \pm 1.66$, $23.55 \pm 1.93$, and $26.22 \pm 1.85 \mathrm{~mm}$ in control, Group A, and Group B, respectively. The difference across the groups was statistically significant $(p=0.010)$. In the post-hoc test, the difference between control and Group B was statistically significant $(p=0.010)$. However, there was no statistically significant difference between Groups A and B ( $p>0.05)$.

\subsection{HR Increased TGF- $\beta 1$, OSX, DSPP, Runx2, BMP-2/4, and PTHrP-R Expression in Tissues}

The administration of $4 \mathrm{HR}$ increased the expression of TGF- $\beta 1$, OSX, DSPP, BMP-2/4, Runx2, and PTHrP-R in both sexes of rats (Figure 3). Full length blot images are available in supplementary data (Figure S3). The difference across groups was significant for TGF- $\beta 1$, OSX, BMP-2/4, Run 2 , and PTHrP-R in the males ( $p=0.049,0.029,0.037,0.004$, and 0.025, respectively). In the post-hoc test, the difference between control and Group B was statistically significant for OSX, BMP-2/4, Runx2, and PTHrP-R ( $p=0.032,0.040,0.005$, and 0.034 , respectively). There was no statistically significant difference between Groups A and B in the males.

The difference across groups was significant for TGF- $\beta 1$, DSPP, OSX, BMP-2/4, Runx2, and PTHrP-R in the females $(p=0.006,0.023,<0.001,0.022,0.001$, and 0.021 , respectively). In the post-hoc test, the difference between control and Group B was statistically significant for TGF- $\beta 1$, DSPP, OSX, BMP-2/4, Runx2, and PTHrP-R ( $p=0.006,0.024,<0.001,0.024,0.001$, and 0.027, respectively). Additionally, the difference between control and Group A was statistically significant for OSX and Runx2 ( $p=0.001$ and 0.011 , respectively). Comparison of Groups A and B showed significant difference for OSX in the females $(p=0.027)$. 


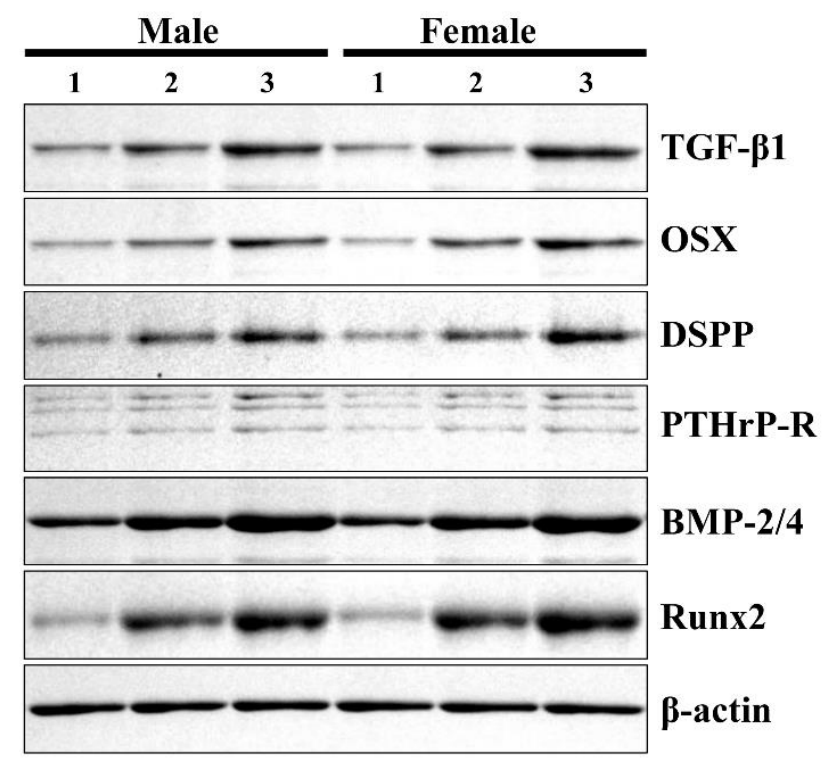

(a)

BMP-2/4

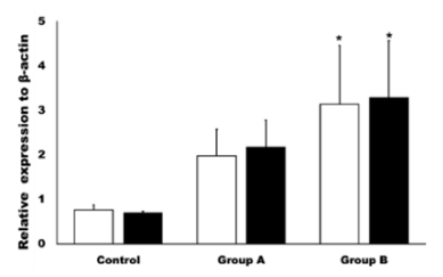

TGF-ק1

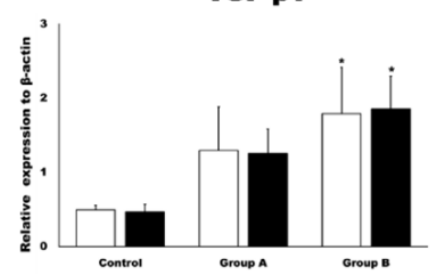

DSPP

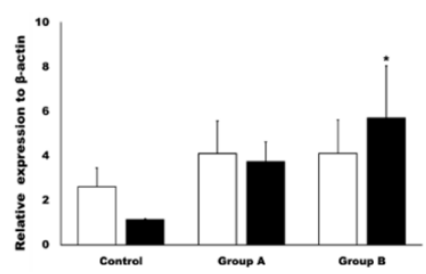

Runx2

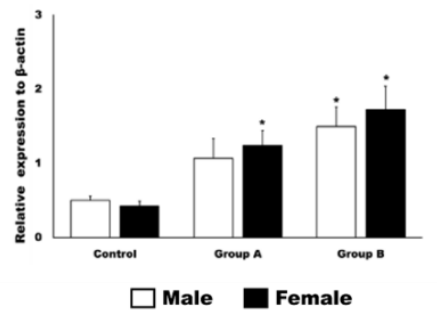

osx

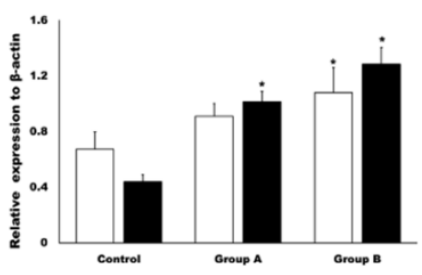

PTHrP-R

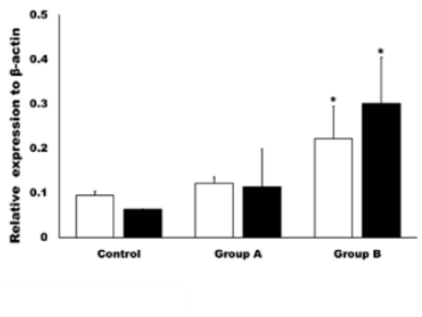

(b)

Figure 3. Western blot results with tissue samples. (a) Representative blot images after $4 \mathrm{HR}$ administration (1: Control, 2: Group A, 3: Group B). The latter increased the expression of TGF- $\beta 1$, OSX, DSPP, BMP-2/4, Runx2, and PTHrP-R. (b) Relative level of protein expression was calculated with reference to that of $\beta$-actin. Compared to control group, Group B showed a significantly higher level of expression $\left({ }^{*} p<0.05\right)$.

The immunohistochemical results demonstrated increased expressions of DSPP, OSX, Runx2, TGF- $\beta 1$, and BMP-2/4 in Groups A and B, compared to those in control group (Figure 4). However, the expression of PTHrP-R was not prominent in these sections. Interestingly, the localization of each protein was specific. While expression of DSPP was observed in the pulp tissue, that of OSX and Runx2 was mainly seen in the odontoblasts. However, TGF- $\beta 1$ was mainly expressed in the ameloblasts. Interestingly, BMP-2/4 was expressed in both odontoblasts and ameloblasts. 

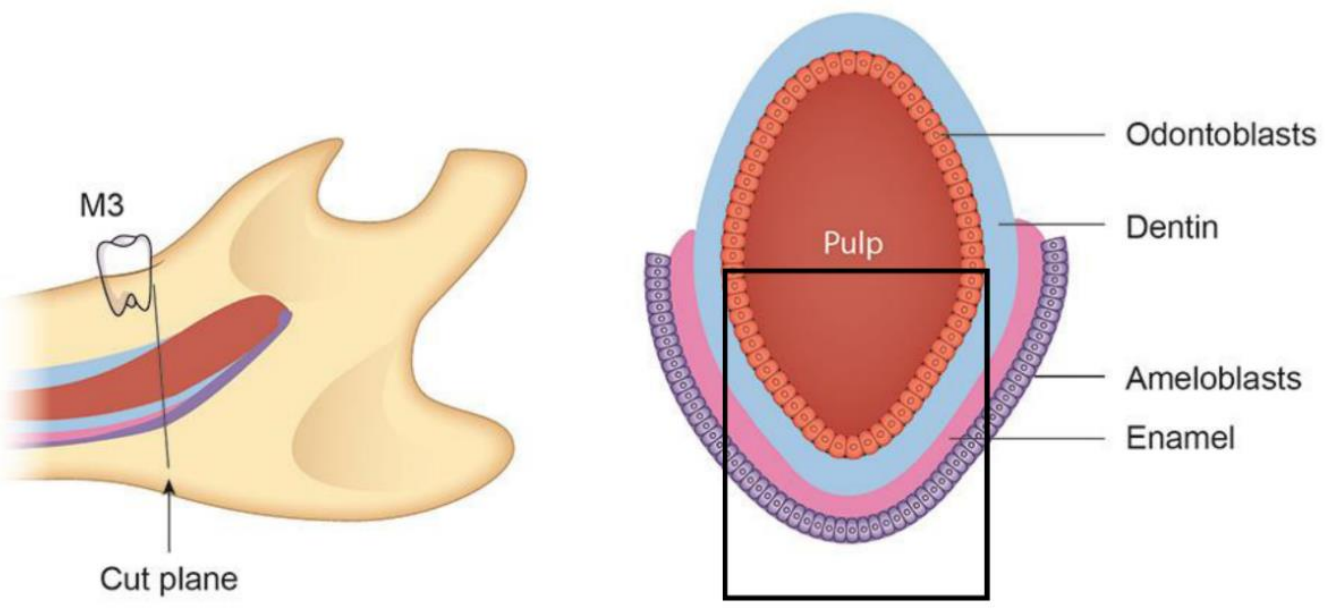

(a)

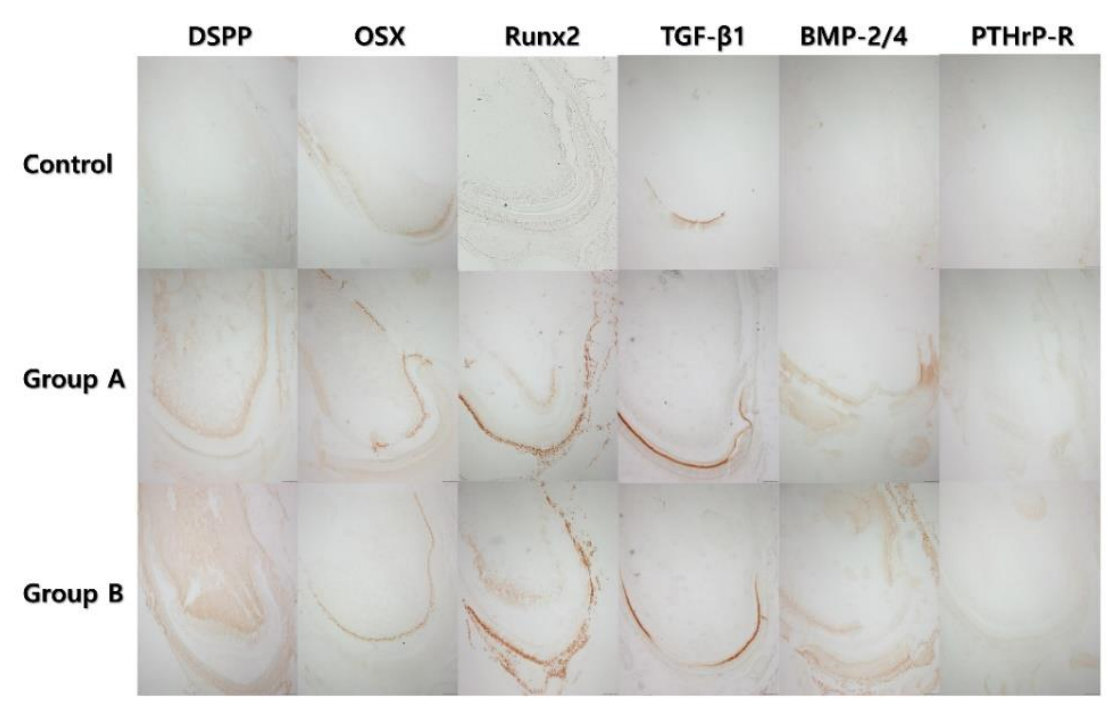

(b)

Figure 4. Results of immunohistochemistry. (a) Schematic drawings of the cut plane. The specimen was cut behind the third molar. The cross-section had ameloblasts and odontoblasts with pulp tissue. The boxed area in the right figure is shown in (b) for immunohistochemical staining. (b) Immunohistochemical staining for DSPP, OSX, Runx2, TGF- $\beta 1$, BMP-2/4, and PTHrP-R. TGF- $\beta 1$ was mainly expressed in the ameloblasts and OSX in the odontoblasts. Runx2 was expressed in both ameloblasts and odontoblasts, though more intensely in the ameloblasts. However, PTHrP-R was not highly expressed in this region.

\section{Discussion}

In our recent study, $4 \mathrm{HR}$ was found to accelerate orthodontic tooth movement by increasing both bone formation and resorption in ovariectomized rats [23]. Since the tooth eruption process requires dental hard tissue formation as well as bone turnover, the current study aimed to explore whether $4 \mathrm{HR}$ could increase both dental hard tissue formation and rate of eruption, using in vivo experiments and evaluating the expression of relevant markers. In vitro experiments using primary cultured rat incisor pulp cells demonstrated that $4 \mathrm{HR}$ administration increased the level of protein expression associated with tooth formation (Figure 1). Accordingly, the total amount of incisor eruption was significantly higher in Group B $(12.8 \mathrm{mg} / \mathrm{kg}$ of $4 \mathrm{HR}$ administered) than that in the untreated control 
$(p<0.05$, Figure 2). In the mandibular tissue samples, expression of proteins associated with tooth formation was higher, and the results were consistent with those of cellular experiments (Figure 3). Interestingly, the localization of their expression was specific in accordance with their role in tooth formation (Figure 4).

Bone is a representative calcified tissue in the body, and 4HR may influence the remodeling of bone via immunomodulation [21]; 4HR is an M2 type macrophage-polarizing agent [21,26]. Tooth is also a kind of calcified tissue, whose eruption rate may be influenced by $4 \mathrm{HR}$ administration. Rat incisors erupt continuously throughout the animal's lifetime $[18,20]$. Indeed, $4 \mathrm{HR}$ administration accelerated mandibular incisor eruption in the $4 \mathrm{HR}$-administered groups (Figure 2a). Administration of $4 \mathrm{HR}$ increased the rate of incisor eruption in both sexes of rats (Figure 2b). The rate of incisor eruption increased with an increase in the dose of $4 \mathrm{HR}$; however, no statistically significant difference was observed between Groups A and B $(p>0.05)$. When the rate of incisor eruption was compared between the sexes within the same group, the total amount of incisor eruption was found to be greater in the females of Group B (Figure $2 b$ ), although the difference was statistically insignificant $(p>0.05)$. According to a previous report, a cut at the mandibular incisor produces hypofunctional eruption conditions, under which the mandibular incisor shows increased eruption rates [3]. The eruption rate of the hypofunctional incisor has been reported to be approximately $1 \mathrm{~mm} /$ day [3] or $1.5 \mathrm{~mm} /$ day [20]. In this study, eruption rates of $1.45 \mathrm{~mm} /$ day for males and $1.46 \mathrm{~mm} /$ day for females were recorded in the untreated control (Figure 2b). Accelerated mandibular incisor eruption after $4 \mathrm{HR}$ administration may be due to the increased level of expression of proteins associated with tooth formation.

$4 \mathrm{HR}$ administration increased TGF- $\beta 1$, BMP-2/4, Runx2, OSX, DSPP, and PTHrP-R expression in both cell culture and tissue samples (Figures 1 and 3 ). It increased the expression of TGF- $\beta 1$ in both RAW264.7 cells [27] and human umbilical vein endothelial cells (HUVECs) [28]. Since TGF- $\beta 1$ plays an important role in cell proliferation and differentiation, as well as in bone and tooth metabolism [5], an increased expression of this cytokine may contribute to the activation of various cells related to tooth eruption. In immunohistochemical study, tissue expression of TGF- $\beta 1$ was mainly localized in the ameloblasts, whereas OSX expression was mainly localized in odontoblasts (Figure 4). Runx2 expression was observed in both odontoblasts and ameloblasts (Figure 4). TGF- $\beta 1$ is important in the maturation stage of ameloblasts [29], and loss of TGF- $\beta 1$ in epithelial cells impairs enamel formation in mice [30]. TGF- $\beta 1$ could also affect enamel mineralization by modulating Runx2 [8]; thus, enamel mineralization in ameloblasts is regulated by TGF- $\beta 1$ and Runx2 [31]. Runx2 and OSX are independently involved in osteoblast differentiation and odontoblast/ameloblast differentiation, to regulate expression of many bone- and tooth-related genes [6-8]. Cross-talk between ameloblasts and odontoblasts is important in tooth development. Accordingly, differential expression patterns of TGF- $\beta 1$, OSX, and Runx2 in tooth development may be associated with programmed differentiation of odontoblasts and ameloblasts.

The expression of BMP-2/BMP-4 was observed not only in odontoblasts, but also in ameloblasts and associated cells (Figure 4). According to previous studies, BMP-2 is required for odontoblast differentiation [32] and is expressed more in the basal part of the dental follicle to promote eruption [33]. BMP-2 also induces DSPP [34], which is important for odontoblast differentiation and dentin formation, forming dental roots [8]. The expression of DSPP was mainly observed in the pulp tissue (Figure 4). The expression level of PTHrP was increased in both cell culture and tissue samples (Figures 1 and 3); however, PTHrP expression was poorly localized in the tissue sections (Figure 4). PTHrP in the dental follicle is known to recruit mononuclear cells by enhancing colony stimulating factor-1 (CSF-1) [35] and vascular endothelial growth factor (VEGF) [36]; thus, the expression of PTHrP may be localized in other areas related to osteoclastogenesis. 4HR-induced TGF- $\beta 1$ and BMP-2 expression is also observed in osteoblast-like cells [23]. It activates the TGF- $\beta / S M A D / V E G F$ pathway in HUVECs [37]. Therefore, increased expression of TGF- $\beta 1$, BMP-2/4, Runx2, OSX, and DSPP in Groups A and B, in this study, may indicate the overall increase in differentiation of dental follicle cells and acceleration of dental hard tissue formation required for tooth eruption by $4 \mathrm{HR}$. 
There are some limitations in this study. First, since the incisors of rats, in this study, had already erupted, the eruption rate was mainly affected by the formation of dental hard tissue, and the effect on intraosseous eruption was not evident. In our previous study [23], 4HR increased both bone resorption and bone formation in orthodontic tooth movement; however, further studies may be required to identify the effects of $4 \mathrm{HR}$ on intraosseous eruption. Second, this study was limited to a selected age group only. There may be some differences in the eruption rate depending on age; in fact, the eruption rate in the same group may also be slightly different, such as $1 \mathrm{~mm} /$ day [3] or $1.5 \mathrm{~mm} /$ day [20]. Third, the effect of $4 \mathrm{HR}$ administration on dental hard tissue formation was mainly shown indirectly by increased incisor eruption rate and expression of related markers in cell culture and tissue samples; it mainly focused on the amount of tooth formation, rather than the degree of calcification. Fourth, humans do not have continuously erupting teeth. Though humans may have unerupted teeth [38], their etiology may not be due to calcification disorder. Accordingly, translated clinical applications based on current results will be limited. In the future, $4 \mathrm{HR}$ may be administered to specific gene knock-out models and its effect on tooth development and eruption may be examined.

\section{Conclusions}

In this study, 4HR administration resulted in increased expression of markers related to dental hard tissue formation in both primary cultured cells and tissue samples. Administration of $4 \mathrm{HR}$ also resulted in accelerated incisor eruption. Overall, the increase in the expression of markers and localized expression patterns indicated the role of $4 \mathrm{HR}$ in programmed cell differentiation and dental hard tissue formation in the odontogenic region of rat incisors.

Supplementary Materials: The following are available online at http://www.mdpi.com/2076-3417/10/16/5511/s1, Figure S1: Full length blot of Figure 1. Figure S2: Relative expression level to $\beta$-actin in the cellular experiments. Figure S3: Full length blot of Figure 3.

Author Contributions: Conceptualization, S.-G.K. and J.-H.K.; methodology, J.-H.K. and D.-W.K.; validation, D.-W.K. and T.-W.K.; formal analysis, S.-G.K.; investigation, S.-G.K.; data curation, D.-W.K.; writing-original draft preparation, S.-G.K. and J.-H.K.; writing-review and editing, T.-W.K.; supervision, T.-W.K.; funding acquisition, S.-G.K. All authors have read and agreed to the published version of the manuscript.

Funding: This study was conducted with the support of "Cooperative Research Program for Agriculture Science and Technology Development (Project no. PJ01313902)" Rural Development Administration, Republic of Korea.

Acknowledgments: Yei-Jin Kang and Ji-hyen Oh helped with the animal experiments.

Conflicts of Interest: The authors declare no conflict of interest.

\section{References}

1. Wise, G.E.; Frazier-Bowers, S.; D'Souza, R.N. Cellular, molecular, and genetic determinants of tooth eruption. Crit. Rev. Oral Biol. Med. 2002, 13, 323-334. [CrossRef] [PubMed]

2. Steedle, J.R.; Proffit, W.R. The pattern and control of eruptive tooth movements. Am. J. Orthod. 1985, 87, 56-66. [CrossRef]

3. Gomes, J.R.; Omar, N.F.; Do Carmo, E.R.; Neves, J.S.; Soares, M.A.M.; Narvaes, E.A.; Novaes, P.D. Relationship between cell proliferation and eruption rate in the rat incisor. Anat. Rec. 2013, 296, 1096-1101. [CrossRef] [PubMed]

4. Shroff, B.; Siegel, S.M. Molecular basis for tooth eruption and its clinical implications in orthodontic tooth movement. Semin. Orthod. 2000, 6, 155-172. [CrossRef]

5. Sakaki-Yumoto, M.; Katsuno, Y.; Derynck, R. TGF- $\beta$ family signaling in stem cells. Biochim. Biophys. Acta 2013, 1830, 2280-2296. [CrossRef]

6. D'Souza, R.N.; Aberg, T.; Gaikwad, J.; Cavender, A.; Owen, M.; Karsenty, G.; Thesleff, I. Cbfa1 is required for epithelial-mesenchymal interactions regulating tooth development in mice. Development 1999, 126, 2911-2920.

7. Zou, S.J.; D'Souza, R.N.; Ahlberg, T.; Bronckers, A.L.J.J. Tooth eruption and cementum formation in the Runx2/Cbfa1 heterozygous mouse. Arch. Oral Biol. 2003, 48, 673-677. [CrossRef] 
8. Chen, S.; Gluhak-Heinrich, J.; Wang, Y.H.; Wu, Y.M.; Chuang, H.H.; Chen, L.; Yuan, G.H.; Dong, J.; Gay, I.; MacDougall, M. Runx2, Osx, and Dspp in tooth development. J. Dent. Res. 2009, 88, 904-909. [CrossRef]

9. Kim, T.H.; Bae, C.H.; Lee, J.C.; Kim, J.E.; Yang, X.; de Crombrugghe, B.; Cho, E.S. Osterix regulates tooth root formation in a site-specific manner. J. Dent. Res. 2015, 94, 430-438. [CrossRef]

10. Ono, W.; Sakagami, N.; Nishimori, S.; Ono, N.; Kronenberg, H.M. Parathyroid hormone receptor signalling in osterix-expressing mesenchymal progenitors is essential for tooth root formation. Nat. Commun. 2016, 7, 11277. [CrossRef]

11. Benker, G.; Breuer, N.; Windeck, R.; Reinwein, D. Calcium metabolism in thyroid disease. J. Endocrinol. Investig. 1988, 11, 61-69. [CrossRef]

12. Suri, L.; Gagari, E.; Vastardis, H. Delayed tooth eruption: Pathogenesis, diagnosis, and treatment. A literature review. Am. J. Orthod. Dentofacial Orthop. 2004, 126, 432-445. [CrossRef] [PubMed]

13. Jensen, B.L.; Kreiborg, S. Development of the dentition in cleidocranial dysplasia. J. Oral Pathol. Med. 1990, 19, 89-93. [CrossRef] [PubMed]

14. Philbrick, W.M.; Dreyer, B.E.; Nakchbandi, I.A.; Karaplis, A.C. Parathyroid hormone-related protein is required for tooth eruption. Proc. Natl. Acad. Sci. USA 1998, 95, 11846-11851. [CrossRef] [PubMed]

15. Proffit, W.R.; Vig, K.W. Primary failure of eruption: A possible cause of posterior open-bite. Am. J. Orthod. 1981, 80, 173-190. [CrossRef]

16. Decker, E.; Stellzig-Eisenhauer, A.; Fiebig, B.S.; Rau, C.; Kress, W.; Saar, K.; Rüschendorf, F.; Hubner, N.; Grimm, T.; Weber, B.H. PTHR1 loss-of-function mutations in familial, nonsyndromic primary failure of tooth eruption. Am. J. Hum. Genet. 2008, 83, 781-786. [CrossRef] [PubMed]

17. Risom, L.; Christoffersen, L.; Daugaard-Jensen, J.; Hove, H.D.; Andersen, H.S.; Andresen, B.S.; Kreiborg, S.; Duno, M. Identification of six novel PTH1R mutations in families with a history of primary failure of tooth eruption. PLoS ONE 2013, 8, e74601. [CrossRef]

18. Grier, R.L.; Wise, G.E. Inhibition of tooth eruption in the rat by a bisphosphonate. J. Dent. Res. 1998, 77, 8-15. [CrossRef]

19. Bradaschia-Correa, V.; Massa, L.F.; Arana-Chavez, V.E. Effects of alendronate on tooth eruption and molar root formation in young growing rats. Cell Tissue Res. 2007, 330, 475-485. [CrossRef]

20. de Araujo, A.M.; Gomes, C.C.; de Almeida, S.M.; Klamt, C.B.; Novaes, P.D. Effect of radiotherapy on the eruption rate and morphology of the odontogenic region of rat incisors. Arch. Oral Biol. 2014, 59, 1242-1248. [CrossRef]

21. Kim, J.-Y.; Seok, H. Role of 4-hexylresorcinol in the field of tissue engineering. Appl. Sci. 2020, 10, 3385. [CrossRef]

22. Song, J.-Y.; Kim, S.-G.; Park, N.-R.; Choi, J.-Y. Porcine bone incorporated with 4-Hexylresorcinol increases new bone formation by suppression of the nuclear factor kappa B signaling pathway. J. Craniofac. Surg. 2018, 29, 1983-1990. [CrossRef] [PubMed]

23. Choi, K.-H.; Kim, D.-W.; Lee, S.K.; Kim, S.-G.; Kim, T.-W. The administration of 4-Hexylresorcinol accelerates orthodontic tooth movement and increases the expression level of bone turnover markers in ovariectomized rats. Int. J. Mol. Sci. 2020, 21, 1526. [CrossRef] [PubMed]

24. Wise, G.E.; King, G.J. Mechanisms of tooth eruption and orthodontic tooth movement. J. Dent. Res. 2008, 87, 414-434. [CrossRef]

25. Jo, Y.-Y.; Kim, D.-W.; Choi, J.-Y.; Kim, S.-G. 4-Hexylresorcinol and silk sericin increase the expression of vascular endothelial growth factor via different pathways. Sci. Rep. 2019, 9, 3448. [CrossRef]

26. Kim, S.-G. Immunomodulation for maxillofacial reconstructive surgery. Maxillofac. Plast. Reconstr. Surg. 2020, 42, 5. [CrossRef]

27. Kim, M.-K.; Yoon, C.-S.; Kim, S.-G.; Park, Y.-W.; Lee, S.-S.; Lee, S.-K. Effects of 4-Hexylresorcinol on protein expressions in RAW 264.7 cells as determined by immunoprecipitation high performance liquid chromatography. Sci. Rep. 2019, 9, 3379. [CrossRef]

28. Kim, D.-W.; Jo, Y.-Y.; Garagiola, U.; Choi, J.-Y.; Kang, Y.-J.; Oh, J.-H.; Kim, S.-G. Increased level of vascular endothelial growth factors by 4 -Hexylresorcinol is mediated by transforming growth factor- $\beta 1$ and accelerates capillary regeneration in the burns in diabetic animals. Int. J. Mol. Sci. 2020, 21, 3473. [CrossRef]

29. Okubo, M.; Chiba, R.; Karakida, T.; Yamazaki, H.; Yamamoto, R.; Kobayashi, S.; Niwa, T.; Margolis, H.C.; Nagano, T.; Yamakoshi, Y.; et al. Potential function of TGF- $\beta$ isoforms in maturation-stage ameloblasts. J. Oral Biosci. 2019, 61, 43-54. [CrossRef] 
30. Song, W.; Wang, Y.; Chu, Q.; Qi, C.; Gao, Y.; Gao, Y.; Xiang, L.; Zhenzhen, X.; Gao, Y. Loss of transforming growth factor- $\beta 1$ in epithelium cells affects enamel formation in mice. Arch. Oral Biol. 2018, 96, 146-154. [CrossRef]

31. Liu, X.; Xu, C.; Tian, Y.; Sun, Y.; Zhang, J.; Bai, J.; Pan, Z.; Feng, W.; Xu, M.; Li, C.; et al. RUNX2 contributes to TGF- $\beta 1$-induced expression of Wdr72 in ameloblasts during enamel mineralization. Biomed. Pharmacother. 2019, 118, 109235. [CrossRef] [PubMed]

32. Yang, W.; Harris, M.A.; Cui, Y.; Mishina, Y.; Harris, S.E.; Gluhak-Heinrich, J. Bmp2 is required for odontoblast differentiation and pulp vasculogenesis. J. Dent. Res. 2012, 91, 58-64. [CrossRef] [PubMed]

33. Wise, G.E.; Yao, S. Regional differences of expression of bone morphogenetic protein-2 and RANKL in the rat dental follicle. Eur. J. Oral Sci. 2006, 114, 512-516. [CrossRef] [PubMed]

34. Yang, G.; Yuan, G.; MacDougall, M.; Zhi, C.; Chen, S. BMP-2 induced Dspp transcription is mediated by Dlx3/Osx signaling pathway in odontoblasts. Sci. Rep. 2017, 7, 10775. [CrossRef]

35. Cielinski, M.J.; Jolie, M.; Wise, G.E.; Marks, S.C. The contrasting effects of colony-stimulating factor-1 and epidermal growth factor on tooth eruption in the rat. Connect. Tissue Res. 1995, 32, 165-169. [CrossRef]

36. Yao, S.; Pan, F.; Wise, G.E. Chronological gene expression of parathyroid hormone-related protein (PTHrP) in the stellate reticulum of the rat: Implications for tooth eruption. Arch. Oral Biol. 2007, 52, 228-232. [CrossRef]

37. Kim, M.-K.; Kim, S.-G.; Lee, S.-K. 4-Hexylresorcinol induced angiogenesis potential in human endothelial cells. Maxillofac. Plast. Reconstr. Surg. 2020, 42, 23. [CrossRef]

38. Dinoi, M.T.; Marchetti, E.; Garagiola, U.; Caruso, S.; Mummolo, S.; Marzo, G. Orthodontic treatment of an unerupted mandibular canine tooth in a patient with mixed dentition: A case report. J. Med. Case Rep. 2016, 10, 170. [CrossRef]

(C) 2020 by the authors. Licensee MDPI, Basel, Switzerland. This article is an open access article distributed under the terms and conditions of the Creative Commons Attribution (CC BY) license (http://creativecommons.org/licenses/by/4.0/). 